\title{
The Impacts of Supply Chain Evolution and Revolution Drivers on Firm Performances and Global Competitiveness
}

\author{
Alie Wube Dametew ${ }^{1,2}$ \\ ${ }^{1}$ School of Mechanical and Industrial Engineering, Addis Ababa Institute of Technology, Addis Ababa University, \\ Addis Abab-Ethiopia \\ ${ }^{2}$ Nuremberg Campus of Technology Hochschule Nürnberg Georg Simon Ohm Nurenebrge, Germany \\ Correspondence: Alie Wube Dametew, PhD Candidate, School of Mechanical and Industrial Engineering, Addis \\ Ababa Institute of Technology, Addis Ababa University, Ethiopia and Nuremberg Campus of Technology Technische \\ Hochschule Nürnberg Georg Simon Ohm Nurenberge, Germany. Tel: 251-913-032-751.
}

Received: August 21, 2019

doi:10.5430/ijba.v10n6p39
Accepted: November 19, 2019

Online Published: November 26, 2019

URL: https://doi.org/10.5430/ijba.v10n6p39

\begin{abstract}
s
The main purpose of this paper is traces to investigate the drivers of supply chain evolution \& revolution and their impacts on firm performance and competitiveness. Through field observation and questionnaire survey, a literature review was supported by an empirical study on supply chain evolution and revolution drivers, the impacts on firm performance and comparative advantages were included. The horizontal relation on the drivers of supply chain integrations was empirically investigated and tested. The primary data and field observation were collected from 21 Ethiopian basic metal industries and 91 respondents incorporated as a case company. Followed by the investigation and explored on how supply chain drivers impacts on firm performance and comparative advantage of manufacturing industries incorporated. While globalization, the digital revolution, social media throughout the society, innovation and new product developments are considered as the main drivers of supply chain evolution and revolutions. Commonly, this supply chain evolution and revolution drivers have a positive impact on firm performance and global competitiveness. Further, the result shows that depending on their type and supply chain scenario the drivers of supply chain evolution and revolution have both positive and negative impacts on firm performances and comparative advantages. Moreover paper investigated the relationship between supply chain evolution and the evolution drivers linkages o supply chain performance and comparative advantages, so that management will be able to pursue better supply chain strategies applicable directly to their business environment. Nevertheless, the study results provide the organization with innovative insights for, controlling adoption and implementation supply chain drivers in the firms.
\end{abstract}

Keywords: supply chain evolution and revolution, drivers, horizontal relation, the impacts, firm performance

\section{Introduction}

The products that consumers demand, factory processes and footprints, and the management of global supply chains are being re-shaped to an unprecedented degree and an unprecedented pace. Though the industry leaders who were consulted believe that new technological solutions heralded through digital supply chains, advanced robotics, autonomous systems and additive manufacturing will revolutionize traditional ways of creating value. However, the resulting greater spatial and temporal flexibility brought about by technology will bring locations of production and sale closer together, and drive major changes in the design of future value and supply chains. These trends will change the shape and form of globalization, and thereby impact the trajectory of goods and manufacturing performances. Likewise, in the evolution and revolution of the supply chain process, the advancement of technology and innovative supply chains can be impacted in terms of the level of readiness and adoption of strategies across industry and sectors in performances and comparative advantages. Likewise, the supply chain evolution providing to impact on impending into how supply chains systems could be modified and provides to help businesses plan their future physical distribution networks and spotlight how developers and investors can unlock value and enhance the performance of their supply chain comparative advantages. Though in a digital supply chain process through advancement and application of technology, data analytics are also enabling a new approach to supply chain performance enhancements. However, the performance was not based on how flexible the supply chain was to 
changes in demand, let alone providing input and feedback to the business as a whole. Rather the supply chain was made up of production lines, trucks, warehouses, pallets, pick/packing, and packing slips - nothing more.

Since the opportunity for the supply chain to grow and increase its influence is significant and underway.

While supply chain has evolved from an internally facing, accounting type function to a one that includes newer roles such as customer demand planning and data analytics. As a result of these changes, in the field of the supply chain is an impact on the performance of firms in terms of quality, flexibility, competitiveness and delivery times. Though effective and efficient innovative supply chain strategies can be essential to improve the performance and competitiveness of the firm in general, and enhancing integrated supply chain systems of developing firms in particular. Besides, many scholars have studied on steel and basic metal industry with the aim of implementing improvement strategies in the sector. Although these provide snapshots of the structure and drivers of supply chain evolution that has occurred is less well understood. Moreover, the horizontal relationship of supply chain drivers and their impacts on the comparative advantage of manufacturing industries needs further investigations. In addition, the driving powers on firms to supply chains toward increased integration were not more studied. Furthermore, the previous stud (Kim, The effect of supply chain integration on the alignment between corporate competitive capability and supply chain operational capability, 2006),(Shaohan Cai a*, 2010), (Kim, 2009) were emphases in small number of variables as presented and studied as a supply chain issue. For instance, (Baofeng Huo, 2014) shows that supply chain variables that impacts on financial performance and customer satisfactions, (Kim, The effect of supply chain integration on the alignment between corporate competitive capability and supply chain operational capability, 2006), (Shaohan Cai a*, 2010) investigates the extra supply chain integration influences for operational performance and product improvement, others believe for quality and resource utilization tools. No single variables but the performance and competitiveness of manufacturing industries in a supply chain systems are highly affected by numerous variables (Mishra, 2014), (Alie Wube Dametew*, 2017). This implies that there were fewer arguments between supply chain scholars with the issue and concepts of supply chain integration influencing variable and the role of supply chain integrations. While these issues need further investigation and researches. Furthermore, there was confusion on the drivers of supply chain evolution and integration. For instance information integration, coordination \& resources sharing, organizational relationship linkage is considered as the drivers of supply chains (Raja Irfan Sabir, 2014). While others believes that commoditization, globalization and the digital revolution are considered as the drivers of supply chain evolution and revolutions (Saideep Raj, 2014), (Sean Ryu, 2008), (Lauri Turja, 2011). However, in this extent researchers bring to miss the concepts of supply chain evolution and revolution drivers and their impacts on firm performance and comparative advantages to manufacturing industries. Though, this study is clearly show the limitation of the previous study related to drivers of supply chain evolution and revolution on firm performances. Therefore, this study is designed to investigate the drivers of supply chain evolution and their impacts on the current business processes to develop models needs further study toward the firm performance improvements. Additionally, this study also to investigate the impacts of supply chain evolution and revolution in the current practice and trends on basic metal industry performances so as to develop an integrated sector performance improvement strategies.

\section{Literature Analysis and Discussions}

\subsection{Introduction}

In this section the importance, the current practices, and the influences of supply chain evolution and revolution drivers to manufacturing industries were incorporated and included. Mainly the digital revolution, globalization, commoditization, social media application, and the unstable worlds are considered as the drivers of supply chain evolution and revolutions (Yitagesu Yilma Goshu*, 2016), (Sean Ryu, 2008), (Sumit Chandak1, 2014), (Abe.et.l, 2015)(Dametew, Ebinger, \& \&Abebe, 2017), (Saideep Raj, 2014), (Kim, The effect of supply chain integration on the alignment between corporate competitive capability and supply chain operational capability, 2006).

\subsection{Drivers of SC Evolution \& Revolutions}

\subsubsection{The Digital Revolution}

The digital trends have led to a growing relevance of new entrants in traditional segments and creation of new segments.

Because, new technologies and service providers make it possible for companies to turn their supply chains into end-to-end business operating strategies (Saideep Raj, 2014). Also have critical impacts to connected cloud enables the real-time collaboration that makes within the firm. Since, digitization in a supply chain systems provides to drive substantial improvements to the value chain through enhanced efficiencies, reduced costs, greater collaboration and 
more innovations of firms (Weinelt, 2016). This crate effective and efficient flow of many, information and material between supply chain firms. Too, digital systems provides to control and manage the flow of product and services, so as to manage resources, connect resources (machines and humans) in real-time, and embrace social media to collaborate beyond organization boundaries, develop working plan and procedures (Saideep Raj, 2014). While digitization and digital revolution impacts all aspects of the firms including arts, entertainment, business, and society, and it's crucial to how products are designed, manufactured, retailer, distributed and customers as well (Alie Wube Dametew*, 2017). Since digitalization and technology critical to allow to how consumers gather and share information, and how they get entertainment, and to how companies manage their finances and operations, how manufacturers follows production systems, so as to meet the goal and objective of the firms.

\subsubsection{Globalization}

Due to globalization, the traditional supply chain systems are evolving towards a globally integrated supply chain-one that operates as a more integrated, optimized and collaborative network across functions, geographies and business partners (Sean Ryu, 2008). Since globalization provides to firms may involve further growth along extension and penetration dimensions and takes various forms. However, globalization has drawn every nation into a single economic system, and through social media, many of us are now participating in a mediated social system as well. Although, as a result of the current globalization, the supply chain firms should focus on exploring innovative methods to reduce operating costs, lead times and inventory to sustain their growth rate in the market (Sumit Chandak1, 2014). As a result, every company's strategy must address a globalized market in which increasing numbers of people are participating in social and business communities that transcend national boundaries. The power and impact of globalization mean that it's essential for every company to understand the current and future impacts of worldwide trends on operations, to develop a globalization strategy to optimize learning opportunities through exposure to various markets around the world, and perhaps also to extend its reach to new customers. As customer communities are also global, no large company can hope to operate successfully without addressing the global market. Besides, globalization has help companies address diverse market requirements, manage input costs, and improve product quality, it has also resulted in greater supply chain complexity and risk. In addition, the process of globalization and increased regional integration has provided impetus for the expansion of value chains, and presented new market opportunities for enterprises, to provide flexible and adaptively to rapidly changing regional and global demand (Abe.et.l, 2015). Thus, the future the business environment of the market will be highly challenging and competitive and therefore an effective and smarter supply chain strategy could be an effective tool for improving the organization competitiveness (Sumit Chandak1, 2014). As a result, manufacturing firms should integrate together with digital supply chain systems to improve their performance and global competitiveness.

\subsubsection{Commoditization}

The word commoditization can be described as the transformation of goods or services into a commodity or to make it suitable as a commercial product. Since, commoditization is provides to develop a (new) product or service and getting it out on the markets, as to achieve a competitive product (Lauri Turja, 2011). However internal commoditization is to ensure that the administrative and process creating work that is already done does not have to be done again. This includes work practices, guidelines, databases, research and development procedures as well as internal product, service and process description.

Although, over time, non-value adding costs get eliminated with cost adjustments whenever possible, with frequent renegotiations, and with supplier learning curves. Since, supply commoditization provides as buyer practices that catalyze cost-reducing activity from suppliers (Seshadri, 2011).

However, for instance the supply chain commoditization, provides the inexorable pressure that drive prices downward, continues to be a formidable competitive force that is manifested in our times in many ways, from the Wal-Martization of the world's retail supply chain and the accompanying outsourcing of manufacturing to Asia, to upheaval in the retail grocery business, to the outsourcing of computer services to India, to the precipitous drop in the price of computing power, to the cheap air fares that we now enjoy. Since, commoditization is usually viewed as an outcome of competitive in the economy, rather than as practices.

\subsubsection{Social Mediaization Throughout Society}

Digital technology becomes progressively more significant as it's applied to more and more functions of life, business, and society. Though, currently business is inconceivable without the internet, and the countless software tools that we use to manage the modern enterprise. Since, in media and entertainment technology, can create a new ecosystems, markets and business environments (Mishra, 2014). Thus social media with internet-based applications 
that build on the ideological and technological foundations of Web 2.0, and that allow the creation and exchange of user generated content (Semah Ibrahim Ben Abdelaziz, 2015). As a result, hundreds of millions of people are using social media platforms like Face book, Myspace, Twitter, and LinkedIn to communicate with one another, which constitutes a trend with enormous momentum, and perhaps enormous importance. Although, a virtual movie-hall where people from across the world are watching the same movie and interacting with one another is no longer limited due to technical barriers and lack of inter-operable technologies (Mishra, 2014). As well, using the help of social media firms discussed, and provided to follow employee involvement, customer engagement, product development and design and supply chain management (Carr, 2017). Since, the social media application in customer engagement exploits the long-term value of customers. As well, social media can be used to achieve substantial business performance improvements. Thus, the use and application of social media have great impacts in the supply chain process to build relationships among supply chain participants. Accordingly, study (Sonja Markova1, 2013), (A. Haro de Rosario, 2013) shows that, the Web 2.0, used as social media provides to increase creativity, information sharing, and collaboration among users and firms. Since, social technologies push toward collaboration rather than exposure and impression. Thus, this social Medias have great impact for effective and efficient business process and enhancing firm information exchange performance improvements.

\subsubsection{The Unstable World}

The ultimate goal of supply chain systems is to meet consumer demand and enhance mutual benefits between the firms. This enhance to more efficient use of resources including labor, inventory, process, technology, stock, and distribution capacity. Even though, in current business environment due to unbalanced supply and demand, natural disasters, supply and demand shocks ,price hikes and sea pirate, the global business environment could be prove volatile (Khan, 2011).As well, due to the potential for nuclear proliferation to cause such a disaster (Erwann O. Michel-Kerjan, 2009). Also, world financial crises, food security, intercontinental pandemics, international security issues, mega-terrorism, cyber-attacks, global warming, and large-scale natural disasters are the main challenges and drivers of a turbulent world. Since the company should be anticipated turbulence, and it should develop strategies to respond and control these turbulent effects. Thus, risk reduction in the supply chain is critical and it requires, integration, careful planning, and coordination, visibility of the supply chain are vital. Meanwhile, these driving forces of commoditization, digitization, social mobilization, globalization, and turbulence is a strategically decisive issue that's central to everything that the organization must understand and plan for improvement and competitiveness. The main points are that each driving forces are not occurring independently on each other. Rather they mutually interdependent, and they feed off of one another. However, as their impacts converge, the result is the potential for thoroughly disruptive acceleration and the amplification of their impact in a way that is decisive and inescapable. Finally according to the figure below shows the driving force of supply chain evolution and revolution includes commoditization, the digital revolution, social mediaization throughout society, globalization, the turbulent world, and acceleration are hinder the performance and competitiveness of manufacturing industries. Particularly these drivers directly impact the performance of manufacturing industries either positively or negatively.

As a result, the evolution and revolution of supply chain performances can depend on the scenario each driving forces

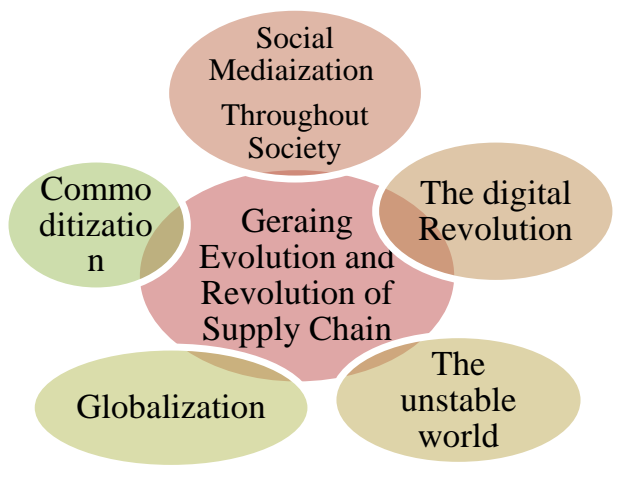

Figure 1. The drivers of supply chain evolution and revolutions 


\subsection{Links Between Supply Chain Revolution Drivers With Firm Performance}

The previous research has explored the relationships between supply chain practices and firm performance including quality, speed, flexibility, financial and production performance. While the globalization, technological change, social media have triste to accelerate the revolution and evolution of supply chain integrations (Saideep Raj, 2014), (Weinelt, 2016), (A. Haro de Rosario, 2013), (Sonja Markova1, 2013), (Sumit Chandak1, 2014), (Abe.et.l, 2015). In this context supply chain revolution drivers including globalization, the application of social media, technological change and strongly impact the performance of manufacturing industries in the positive manner. Thus, previous literature has offered insight on potential arrangements of supply-chain revolutions to firm performance and global competitiveness. Besides, due to uncertainty of materials, unstable world, the formation of nuclear energy, supply chain process were revolved to resist this challenges and constraints (Mishra, 2014), (Alie Wube Dametew*, 2017), (Khan, 2011), (Erwann O. Michel-Kerjan, 2009). As a result of this the performance of manufacturing industries can hinder by the driver of supply chain revolution in the negative way. Thus the drivers of supply chain revolutions have a positive or negative impact for the performance and global competitiveness of manufacturing firms.

\section{Research Methodology}

Research Instrument and Target Groups: Mainly in this study, the descriptive survey design was adopted in conducting this study. While the study tactic involves a literature survey, primary data collection, filed observation, analysis, comparison correlation between variables were employed. Thus, the literature review supported by an empirical study on supply chain evolution and revolution drivers, the impacts of the drivers on firm performance and comparative advantages were included. The horizontal relation on the drivers of supply chain integrations was empirically investigated and tested. The questionnaire in this was distributed responses from 21 Ethiopian basic metal industry and 91 respondents including production heads, quality managers, section leader, and expertise were incorporated. The distributed questionnaire contains three sections, the drivers of supply chain evolution and revolution, the impacts of supply chain evolution on firm performance and the current practices of basic metal industry supply chain integrations were incorporated. While the research questions were answered using a five-point, Likert- scale such as $1=$ not impact, $2=$ lower impact, $3=$ medium impact, $4=$ highest, $5=$ very higher impact were considered. In the first section questions aligned with the investigation of supply chain revolution driver and supply chain revolution practices in the regional metal industries employed. The second and the third section questions focused on the impacts of each driver in performance in quality, speed, flexibility, finance and production performances to basic metal industries. While the questions about the influence of supply chain revolution driver, the influence of the supply chain evolution, revolution, and supply chain practices in the firm performance, factors were answered using these five-point Likert scale.

Moreover, this primary data collection also employed, a field observation which helps the researchers to triangulate the responses those obtained from interview discussion and company manuals.

Data Analysis and Interpretations: Bothe the primary and secondary collected data was analyzed using fuzzy TOPSIS and Statistical Package for Social Science (SPSS).

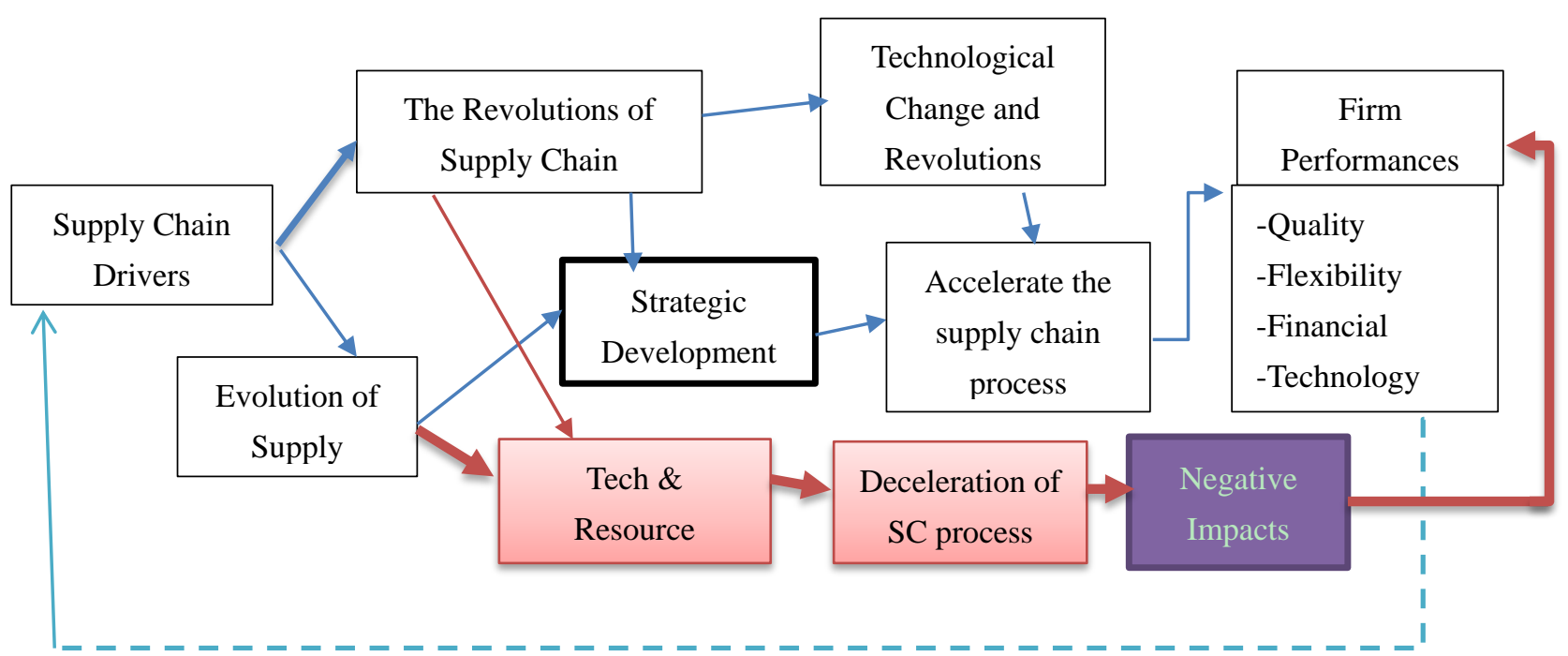

Figure 2. Supply chain evolution and revolution drivers, impacts and firm performance relation 


\section{Result and Discussion}

The capability of the supply chain is influenced by these supply chain evolution drivers. Since evaluation and analysis of supply chain drivers are the most crucial part of firm performance improvement and comparative advantages. As a result, it is compulsory to consider the important evaluate the highest impacts drivers on supply chain revolutions on manufacturing industries. However, the evolution and revolution drivers provide a useful framework in which the firm to think about supply chain capabilities and enhancing innovative supply chain strategies. Because innovative supply chain strategies have the opportunity to make a major impact on the supply chain systems. While this driving force evaluation results to minimize risk and increase the comparative advantages of the firm. Moreover, capable supply chain systems are provided to transform data, integrate, collect, process and communicate critical information across the entire supply chain. This assures through digitalization IT base supply chain enablers. In this digitalization and advancement of supply chains developments of business-to-business (B2B) integration, business-to-consumer (B2C) e-commerce is highly impacting the supply chain for all supplier, distributor, retailers' manufacturers and customers. In this scenario the supply chain drivers used as an enabler on firm performance and enhancing comparative advantages.

\subsection{Fuzzy Prioritization on the Drivers of Supply Chain Evolution and Revolutions}

Under this section, the impacts of various drivers on supply chain evolution and revolutions were periotaized and ranked. As shown in the literature section (Mishra, 2014), (Alie Wube Dametew*, 2017), the digital revolution and the digital revolution, social mediaization throughout society, customer focuses business process, technology change and technological uncertainty, globalization and the opportunity of new markets and their effects, commoditization unstable world, demand and supply uncertainties were considered as the main drivers and impacts on supply chain evolution and revolutions. Due to these drivers, the supply chain was evolve and revolved from one stage to the next stages (Emilio Esposito, 2009), (Hsiu-Chun Cheng, 2010). Thus, the ranking and prioritization of supply chain drivers can be crucial for the new systems development and manufacturing industry performances.

Table 1. The comparative analysis of supply chain drivers impacts for supply chain evolution and revolutions

\begin{tabular}{llll}
\hline Drivers of Supply Chain Revolutions & $\left(\mathrm{CC}_{\mathrm{i}}\right)=\left(\mathrm{D}^{-} /\left(\mathrm{D}^{-}+\mathrm{D}^{*}\right)\right.$ & $\begin{array}{l}\text { Normalized Cumulative } \\
\text { weight }\end{array}$ & Rank \\
\hline The Digital Revolution and The Digital Revolution & 0.518 & 0.185654 & 1 \\
\hline Social Mediaization Throughout Society & 0.519 & 0.167194 & 2 \\
\hline Customer Focuses Business Process & 0.520 & 0.16403 & 3 \\
\hline $\begin{array}{l}\text { Technology Change and Technological Uncertainty } \\
\begin{array}{l}\text { Globalization and Opportunity of new markets and } \\
\text { their effects }\end{array}\end{array}$ & 0.521 & 0.157173 & 4 \\
\hline Commoditization & 0.525 & 0.129747 & 5 \\
\hline Unstable World & 0.533 & 0.128692 & 6 \\
\hline Demand and supply uncertainties & 0.605 & 0.048523 & 7 \\
\hline
\end{tabular}




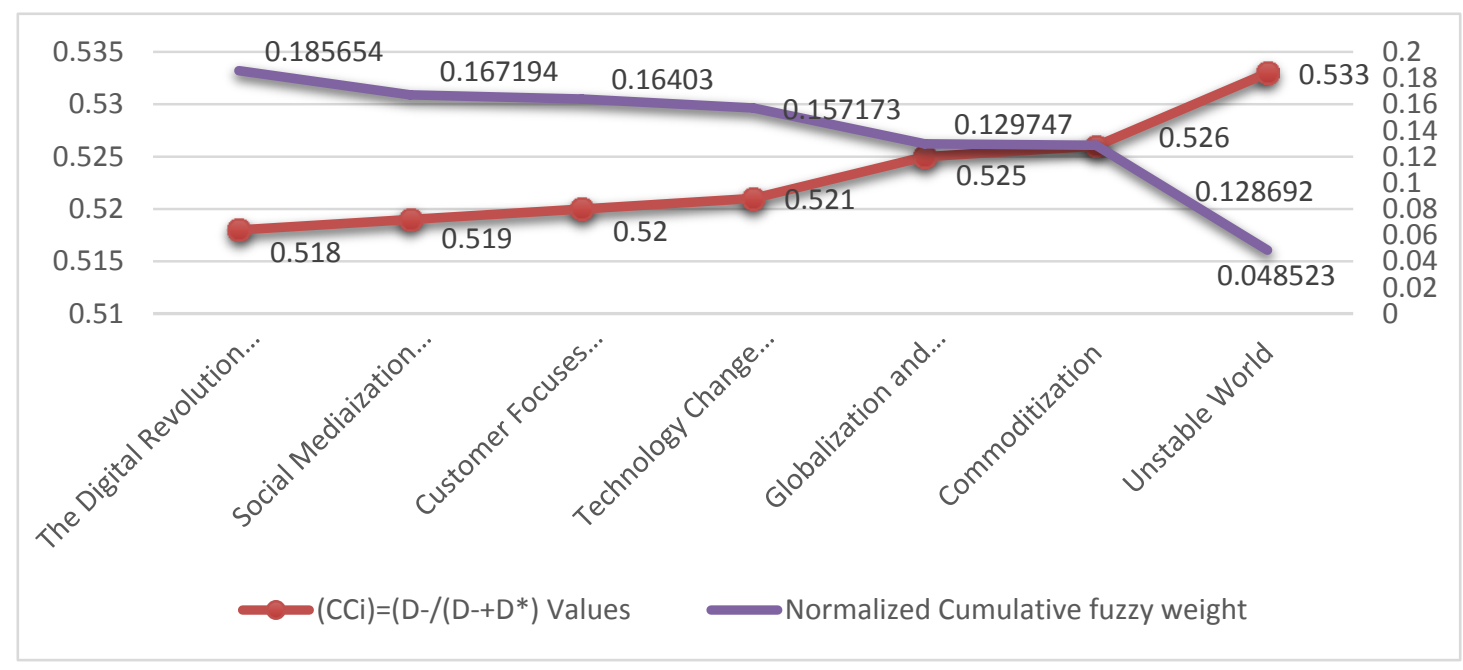

Figure 3. Fuzzy closeness coefficient and the fuzzy weighting of supply chain evolution and revolution drivers

This fuzzy TOPSIS analysis rank in (table 8-10) and (figure.5) above shows that, the digital revolution and the digital revolution is the highest and demand and supply uncertainties are the lowest positive drivers on the evolution and revolution supply chain systems. In other words the digital revolution and the digital revolution, social mediaization throughout society, the customer focuses business process has the highest positive impact on the performance and competitiveness of supply chain evolution and revolutions to manufacturing industries. Besides, demand and supply -uncertainties, the unstable world, commoditization, globalization, and opportunity of new markets have a negative impact on the evolution and revolution of the supply chain systems. Due to these influences, the performance and competitiveness of manufacturing industries are highly impacted and crushed.

\subsection{Statistical Analysis on the Drivers of Supply Chain Evolution and Revolutions Impacts}

Based on the -5 to +5 Likert scale ranking system, the impacts of supply chain revolution drivers in the supply chain evolution and revolution process was investigated in the following tables. Mainly, the descriptive statistics correlation, one sample t-test, and the bivariate correlation analysis on supply chain evolution and revolution with various drivers were employed. Accordingly the horizontal relation supply chain evolution and revolutions, the digital revolution to the digitalization, globalization, and opportunity of new markets, social mediaization throughout society, unstable world, demand and supply uncertainties, technology change and technological uncertainty, commoditization and customer focus business also determined and studied.

Table 2. The comparative analysis on the impacts of supply chain drivers with supply chain evolution and revolution from various experts/inputs

\begin{tabular}{llccc}
\hline List of drivers & Mean & Median & $\begin{array}{l}\text { Std. } \\
\text { Deviation }\end{array}$ & $\begin{array}{l}\text { Std. } \\
\text { Mean }\end{array}$ \\
\hline Supply Chain Evolution and Revolutions & 3.920000 & 4.000000 & .8290639 & .1172473 \\
\hline The Digital Revolution The Digitalization(DR.IOT) & 4.000000 & 4.000000 & .8571429 & .1212183 \\
\hline $\begin{array}{l}\text { Globalization and Opportunity of new markets and } \\
\text { their effects(GZ0) }\end{array}$ & 3.040000 & 3.000000 & 1.5113178 & .2137326 \\
\hline Social Mediaization Throughout Society(SM) & 3.480000 & 3.000000 & 1.1292042 & .1596936 \\
\hline Unstable World(UW) & -.180000 & 1.000000 & 2.7081886 & .3829957 \\
\hline Demand and supply uncertainties(DSU) & -.040000 & .000000 & 2.0991738 & .2968680 \\
\hline Technology Change and Technological Uncertainty & 3.880000 & 4.000000 & 1.2229105 & .1729457 \\
\hline Commoditization(CD) & 2.800000 & 3.000000 & 1.3552619 & .1916630 \\
\hline Customer focuses Business(CFB) & 3.840000 & 4.000000 & 1.0173996 & .1438820 \\
\hline
\end{tabular}


Table 3. The bivariate correlation analysis on supply chain evolution and revolution with various drivers

\begin{tabular}{|c|c|c|c|c|c|c|c|c|c|c|}
\hline \multicolumn{11}{|c|}{ Correlations } \\
\hline \multicolumn{2}{|c|}{ List of drivers } & SCE\&R & DR.IOT & GZ & SM & UW & DSU & TC\&TU & $\mathrm{CD}$ & CFB \\
\hline SCE\&R & $\begin{array}{l}\text { Pearson } \\
\text { Correlation }\end{array}$ & 1 & & & & & & & & \\
\hline DR.IOT & $\begin{array}{l}\text { Pearson } \\
\text { Correlation }\end{array}$ & .258 & 1 & & & & & & & \\
\hline GZ & $\begin{array}{l}\text { Pearson } \\
\text { Correlation }\end{array}$ & .019 & $-.331^{*}$ & 1 & & & & & & \\
\hline SM & $\begin{array}{l}\text { Pearson } \\
\text { Correlation }\end{array}$ & .216 & $.548^{* *}$ & -.023 & 1 & & & & & \\
\hline UW & $\begin{array}{l}\text { Pearson } \\
\text { Correlation }\end{array}$ & .057 & .009 & .256 & .242 & 1 & & & & \\
\hline DSU & $\begin{array}{l}\text { Pearson } \\
\text { Correlation }\end{array}$ & .057 & -.136 & $-.289^{*}$ & -.061 & .200 & 1 & & & \\
\hline TC\&TU & $\begin{array}{l}\text { Pearson } \\
\text { Correlation }\end{array}$ & .151 & .058 & -.019 & .205 & -.025 & .086 & 1 & & \\
\hline $\mathrm{CD}$ & $\begin{array}{l}\text { Pearson } \\
\text { Correlation }\end{array}$ & .022 & .053 & -.016 & .104 & -.171 & .126 & $.429^{* *}$ & 1 & \\
\hline $\mathrm{CFB}$ & $\begin{array}{l}\text { Pearson } \\
\text { Correlation }\end{array}$ & .178 & .140 & .031 & -.127 & $-.351^{*}$ & -.041 & .115 & $.657^{* *}$ & 1 \\
\hline
\end{tabular}

Table 4. One Sample T-test values supply chain evolution and revolution driving variables

\section{One-Sample Test}

\begin{tabular}{|c|c|c|c|c|c|c|}
\hline \multirow{3}{*}{ List of drivers } & \multicolumn{6}{|c|}{ Test Value $=0$} \\
\hline & \multirow[t]{2}{*}{$\mathrm{t}$} & \multirow[t]{2}{*}{$\mathrm{df}$} & \multirow[t]{2}{*}{$\begin{array}{l}\text { Sig. } \\
\text { (2-tailed) }\end{array}$} & \multirow[t]{2}{*}{$\begin{array}{l}\text { Mean } \\
\text { Difference }\end{array}$} & \multicolumn{2}{|c|}{$\begin{array}{l}95 \% \text { Confidence Interval of } \\
\text { the Difference }\end{array}$} \\
\hline & & & & & Lower & Upper \\
\hline $\begin{array}{l}\text { Supply Chain Evolution and } \\
\text { Revolutions }\end{array}$ & 33.434 & 49 & .000 & 3.9200000 & 3.684383 & 4.155617 \\
\hline $\begin{array}{l}\text { The Digital Revolution The Digital } \\
\text { Revolution }\end{array}$ & 32.998 & 49 & .000 & 4.0000000 & 3.756403 & 4.243597 \\
\hline $\begin{array}{l}\text { Globalization and Opportunity of } \\
\text { new markets and their effects }\end{array}$ & 14.223 & 49 & .000 & 3.0400000 & 2.610488 & 3.469512 \\
\hline $\begin{array}{l}\text { Social Mediaization Throughout } \\
\text { Society }\end{array}$ & 21.792 & 49 & .000 & 3.4800000 & 3.159084 & 3.800916 \\
\hline Unstable World & -.470 & 49 & .640 & -.1800000 & -.949659 & .589659 \\
\hline Demand and supply uncertainties & -.135 & 49 & .893 & -.0400000 & -.636579 & .556579 \\
\hline $\begin{array}{l}\text { Technology Change } \\
\text { Technological Uncertainty }\end{array}$ & 22.435 & 49 & .000 & 3.8800000 & 3.532453 & 4.227547 \\
\hline Commoditization & 14.609 & 49 & .000 & 2.8000000 & 2.414839 & 3.185161 \\
\hline Customer focuses Business & 26.689 & 49 & .000 & 3.8400000 & 3.550858 & 4.129142 \\
\hline
\end{tabular}


Correlation analysis in the above tables shows that in most case there is a significant and moderate positive correlation between supply chain evolution and revolution practices with the drivers of supply chain evolutions. But within a zero t-test value, demand and supply uncertainties, the impacts of an unstable world have a negative impact on the evolution and revolutions of the current supply chain process to manufacturing industries. This implies that due to the unstable world, and unbalanced either material or products to the current business environment, the change, and transformation of supply chain integrations are highly hacked and negatively impacts firm performance and global competitiveness. Particularly, the supply chain systems are more challenged in the developing world than the developed one. Because, till now the production, supply chain systems and most business process in the case of developing worlds are non-integrated, paperwork, and fragmental systems (Habib, 2011), (Emilio Esposito, 2009). As a result, the performance and competitiveness of developing industries are weak and infant at regional and global markets. Furthermore, both fuzzy and statistical correlation analysis shows that the digital revolution the digitization, globalization and the opportunity of a new market, social mediaization throughout society, the unstable world, demand, and supply uncertainties, technology change, and technological uncertainty, commoditization customer focuses business practices were properly studied and investigated. This empirical result clearly shows that the digital revolution and the digitization, social mediaization throughout society, the customer focuses business process are the highest drivers of the evolution and revolutions of the supply chain process. Some drivers have a higher positive impact and negative impact on the performance and competitiveness of manufacturing industries. For instance, the digital revolution and the digital revolution, social mediaization throughout society, customer focuses business the process has the highest positive impact on the performance and competitiveness of manufacturing industries. Because these drivers are strongly correlated supply chain evolution and revolutions. However, globalization and opportunity of new markets and their effects, unstable world, demand, and supply uncertainties have the lowest positive and highest negative impact on the performance and competitiveness of manufacturing industries. Our study also indicates that due to the driver's supply chain integration revolves technologically from manual to digitalized systems. Whereas, in the system, wise the supply chain process changes to integrated, collaborative way from the non-integrated and fragmental process. Thus, the evolution and revolution of supply chain integrations have a positive impact on firm performances and global competitiveness.

Therefore, for competitive and industrial performance, firms highly considered on the influence these supply chain drivers for further model development and strategic implementations.

\section{Research Conclusion}

Using primary and secondary data this study was conducted to investigate the drivers of supply chain evolution and revolution, and their impacts on firm performances and comparative advantages. Particularly the firm performance on quality, flexibility, financial, technology, and resource utilization were studded and investigated. However, firm performances cannot be thought in a box without the consideration of an integrated supply chain process, and strong collaboration with supply chain drivers with revolution and evolutions of the supply chain process. Moreover, the horizontal relations of various supply chain revolution drivers on basic metal industries performance were studied and incorporated. The study too acquired Ethiopian basic metal industries supply chain practice case companies using interview questions and field observation. It supported to triangulate the literature and the standpoint of the researchers to recapitulate how the supply chain revolution and evolution drivers impact basic metal industries performance and competitiveness at national and regional levels. While the fuzzy and statistical correlation analysis shows that the digital revolution the digitalization, globalization and the opportunity of a new market, social mediaization throughout society, the unstable world, demand and supply uncertainties, technology change and technological uncertainty, commoditization customer focuses business practices have an impact on the performance and competitiveness of manufacturing industries.

Specifically the digitalization, social media, globalization and the opportunity of a new market, and colorizations have appositive impact on firm performance in quality, quality speed, flexibility and finances to basic metal industries. Besides

Technological uncertainty, unbalanced world, demand supply uncertainty, and resource uncertainty have a negative impact on firm performance and comparative advantages. This variable hacks the overall GDP contribution and global competitiveness of manufacturing industries in general basic metal industries in particular.

\section{Recommendation and Implications}

The conclusions and directions are done based on the author's understanding of the events surrounding the drivers of supply chain evolution, revolution and their impacts on the performance and comparative advantages of basic metal industries in general. Mainly this paper investigated the relationship between supply chain evolution and the 
evolution drivers linkages o supply chain performance and comparative advantages, so that management will be able to pursue better supply chain strategies applicably directly to their business environment. Though the study results provide an organization with innovative insights for, controlling adoption and implementation supply chain drivers in the firms. Finally the recommendation is drawn-out from the discussions above on some sort of ideas for further research areas. Researchers can go further on social, cultural and economic efficiency and supply chain integration interrelation with sustainable firm performances will be considered. Lastly, on the impacts of supply chain evolution and revolution driver's relations with supply chain ecosystems and their impacts on any manufacturing industries can be considered.

\section{References}

Arturo, H. de R., María, del M. G. R., \& María, del C. C. P. (2013). Development of social media and web 2.0 in the top hotel chains. Tourism \& Management Studies, 9(1), 13-19.

Abe, M., et al. (2015). Integrating smes into global value chains challenges and policy actions in Asia. Asian Development Bank, Asian Development Bank Institute.

Alie, W. D., \& Frank, E. (2017). Technological Innovations as a Potential Vehicle for Supply Chain Integration on Basic Metal Industries. International Journal of Swarm Intelligence and Evolutionary Computation, 6(2), 1000159. https://doi.org/10.4172/2090-4908.1000159

Huo, B. F., Qi, Y. N., Wang, Z. Q., Zhao, X. D. (2014). The impact of supply chain integration on firm performance.

Supply Chain Management: An International Journal, 19(4), 69-384. https://doi.org/10.1108/SCM-03-2013-0096

Carr, P. (2017). Whole Enterprise Social Media for Business Performance. Springer International Publishing Switzerland. University of Waterloo, 200 University Avenue West, Waterloo, Canada N2L 3G1. https://doi.org/10.1007/978-3-319-44468-0_2

Dametew, A. W., Ebinger, F., \& Abebe, B. B. (2017). Performance Analysis on the Demand and Supply of Basic Metal Products: Focused On Ethiopian Basic Metal Industries. International Journal of Scientific \& Engineering Research, 8(8), 14.

Emilio, E., \& Renato, P. (2009). Evolution of the supply chain in the Italian railway industry, Supply Chain. Supply Chain Management: An International Journal, 14(4). https://doi.org/10.1108/13598540910970135

Erwann, O., \& Michel-Kerjan, D. K. (2009). Resilience in a Turbulent World.

Habib, M. (2011). Supply Chain Management (SCM): Theory and Evolution. Supply Chain Management Applications and Simulations. https://doi.org/10.5772/24573

Hsiu-Chun, C. M.-C. C.-K. (2010). The evolutionary process and collaboration in supply chains. Industrial Management \& Data Systems, 110(3), 453-474. https://doi.org/10.1108/02635571011030079

Khan, M. L. (2011, April 8-10). Developing a more robust approach to global supply chaininformation systems in a turbulent world. In Proceedings of the 9th Annual Conference on Telecommunications Systems \& Information Technology (ITERA). Indianapolis, Indiana, USA. https://doi.org/10.2139/ssrn.2579571

Kim, S. W. (2006). The effect of supply chain integration on the alignment between corporate competitive capability and supply chain operational capability. International Journal of Operations \& Production Management, 6(10), 084-1107. https://doi.org/10.1108/01443570610691085

Kim, S. W. (2009). An investigation nonth edirect an dindirect effect of supply chain in tegration on firm $\begin{array}{lllll}\text { performance. International Journal Production } & \text { Economics, } & 119, & 328-346 .\end{array}$ https://doi.org/10.1016/j.ijpe.2009.03.007

Klas, H., \& Lauri, T. (2011). Commoditization. Klas Holmberg: Prcada.

Mishra, D. (2014). The New Digital Supply Chain. Media \& Entertainment Services Alliance (MESA).

Raja, I. S., \& Muhammad, I. (2014). Levels and Barriers to Supply Chain Integration: A conceptual model of Supply Chain Performance. International Journal of Management Science and Business Administration, 1(1), 52-59. https://doi.org/10.18775/ijmsba.1849-5664-5419.2014.11.1005

Saideep, R., \& Aditya, S. (2014). Supply chain management in the cloud. Accenture.

Sean, R., Michelle, K., Zhan, Y., Jiang, Y. W., \& Yang, C. (2008). Globally Integrated Supply Chain China perspective. U.S.A NY: IBM Institute for Business Value/Supply Chain Managment. 
Semah, I. B. A., Ahmed, Z. B., \& Muhammad, A. S. (2015). Social Media Effect on Sustainable Products Purchase. Proceedings of the Hamburg International Conference of Logistics (HICL) - 21. Epubli GmbH.

Seshadri, S. (2011). Innovation and Commoditization: Prioritizing and Profiling Asian Managers' Cross-Border Sourcing Practices. Journal of Strategic Innovation and Sustainability, 7(1), 43-61.

Cai, S. H., Jun, M. J., \& Yang, Z. L. (2010). Implementing supply chain information integration in China: The role ofinstitutional forces and trust. Journal of Operations Management, 28, 257-268. https://doi.org/10.1016/j.jom.2009.11.005

Sonja Markova, T. P.-M. (2013). Social media and supply chain. Supply Chain Management, 4(33).

Sumit, C., Amit, C., \& Advait, S. (2014). Globalisation of Supply Chain Management for an Automotive Industry-future Perspective. International Review of Applied Engineering Research, 4(2), 155-164.

Weinelt, B. (2016). Digital Transformation of Industries Automotive Industry. World Economic Forum White Paper.

Goshu, Y. Y., \& Kitaw, D. (2016). Performance measurement and its recent challenge: a literature review. International Journal Business Performance Management. 